\title{
Validation of the Serological Testing for Anti-HIV-1/2, Anti-HCV, HBsAg, and Anti-HBc from Post-mortem Blood on the Siemens-BEP-III Automatic System
}

\author{
Ulrich Kalus $^{a}$ Ina Wilkemeyer ${ }^{a}$ Gregor Caspari ${ }^{b}$ Jan Schroeter ${ }^{a *}$ Axel Pruss $^{a *}$ \\ a University Tissue Bank, Institute of Transfusion Medicine, Charité - University Medicine Berlin, \\ ${ }^{\mathrm{b}}$ LADR GmbH, Medical Care Center Berlin, Germany
}

\section{Keywords}

Infectious disease serology - Post-mortem blood . Tissue donation · BEP-III · Validation

\section{Summary}

Background: Some properties of blood are modified post mortem. These modifications might give false-negative or false-positive results in infectious disease testing. Most CE-marked test equipment for infectious serology testing is not validated for testing post-mortal blood. Validation, however, is obligatory, if the results are used for the release of tissues for transplantation. Methods: Samples of pre- and post-mortem sera were obtained from 20 cornea donors, and the results were compared for anti-HIV-1/2, anti-HCV, HBsAg, and anti-HBc on the Siemens-BEP-III Automatic System. Negative post-mortem sera were spiked with standard sera (PEI anti-HCV IgG, PEI HBsAg ad 1000 standard, anti-HBc IgG (WHO) NIBSC 95/522, PEI anti-HIVIV) in concentrations which give low- and high-positive results for the respective marker. Results: All pre-mortem sera were negative for all markers. None of the post-mortem samples was false-positive. None of the spiked postmortem samples was false-negative. Technical errors occurred during the validation process but could be detected and eliminated. Serum samples should be centrifuged immediately after collection, and it must be taken into account that post-mortem serum could rarely lead to blockage of pipetting systems due to clotting phenomena. Conclusion: There is no indication that post-mortem samples give false-negative or false-positve results with the test system and test kits used. The procedure described might serve as a model for validating other test kits on post-mortem samples.

\footnotetext{
*Authors shared senior authorship
}

\section{Schlüsselwörter}

Infektionsserologie - Post-mortem-Blut . Gewebespende · BEP-III · Validierung

\section{Zusammenfassung}

Hintergrund: Einige Eigenschaften des Blutes können sich post mortem ändern. Hierdurch kann es zu falsch-negativen oder falsch-positiven Ergebnissen in der infektionsserologischen Testung kommen. Die meisten CE-markierten infektionsserologischen Tests sind nicht für die Verwendung von postmortalem Blut validiert. Da die infektionsserologischen Ergebnisse für die Freigabe von Geweben zu Transplantationszwecken vorgeschrieben ist, muss die jeweilige Testung validiert werden. Methoden: Prae- und Post-mortem-Seren von 20 Hornhautspendern wurden auf Anti-HIV-1/2, Anti-HCV, HBsAg und Anti-HBc mit dem Siemens-BEP-III-Automatic-System getestet und miteinander verglichen. Negative Post-mortem-Seren wurden darüber hinaus mit Standardseren (PEI Anti-HCV IgG, PEI HBsAg ad 1000 Standard, Anti-HBc-lgG (WHO) NIBSC 95/522, PEI Anti-HIV-IV) in zwei Konzentrationen gespikt (low level und high level) und getestet. Ergebnisse: Alle Prae-mortem-Seren wurden korrekt negativ für alle Parameter getestet. Keine der Post-mortem-Proben wurde falsch-positiv getestet. Keine der gespikten Post-mortemProben wurde falsch-negativ getestet. Technische Fehler traten bei der Validierung auf, konnten aber erkannt und beseitigt werden. Serumproben sollten sofort nach der Blutentnahme zentrifugiert werden. Es muss berücksichtigt werden, dass Post-mortem-Serum in seltenen Fällen zur Verstopfung der Pipettiersysteme durch Clotting führen kann. Schlussfolgerung: Es gibt keine Anzeichen dafür, dass Post-mortem-Proben mit dem verwendeten Testsystem zu falsch-negativen oder falsch-positiven Ergebnissen führen. Die beschriebene Vorgehensweise könnte als Modell für die Validierung postmortaler Proben mit weiteren Testsystemen dienen.

\begin{tabular}{ll}
\hline KARGER & @ 2011 S. Karger GmbH, Freiburg \\
Fax+497614520714 & Accessible online at: \\
Information@Karger.de & www.karger.com/tmh \\
www.karger.com &
\end{tabular}

Dr. Ulrich Kalus

University Tissue Bank, Institute of Transfusion Medicine, CC14

Charité - University Medicine Berlin

Charité-Platz 1, 10117 Berlin, Germany

Tel. +49 30 450-625317, Fax -525976

ulrich.kalus@charite.de 


\section{Introduction}

The spectrum of transplanted tissues ranges from musculoskeletal preparations (bone, cartilage, tendons, ligaments, fascia) over cornea to cardiovascular allografts (aortic valves, pulmonary valves, pericardium, veins, arteries). Each year about 30,000-35,000 tissue preparations are transplanted in Germany.

Donor suitability criteria regarding blood donors and tissue donors have many points in common. The basic requirements for the viral safety of blood donations were defined in the Guidelines for the Preparation of Blood and Blood Components and for the Application of Blood Products (Hemotherapy) (Richtlinien zur Gewinnung von Blut und Blutbestandteilen und zur Anwendung von Blutprodukten (Hämotherapie)) [1] and for tissue donations in the EU directives 2004/23/EC and 2006/17/EC [2, 3], as well as in accompanying regulations. While serological tests are mandatory for blood and tissue donors, nucleic acid detection (e.g. HIV, HBV, $\mathrm{HCV}$ ) is not explicitly required by the EU directives 2006/17/ EC for tissue donors. In accordance to Annex 3 of the Regulation on Quality and Safety Requirements Regarding Tssue Removal and Transplantation according to the German Transplant Law (Verordnung über die Anforderungen an Qualität und Sicherheit der Entnahme von Geweben und deren Übertragung nach dem Transplantationsgesetz; TPGGewV') of March 26, 2008 [4] serological tests for anti-HIV1/2, HBsAg, anti-HBc, anti-HCV, Treponema pallidum hemagglutination (TPHA) are required for tissue donors in Germany.

In accordance with the EU directive 2006/17, pre-mortem blood samples from the deceased donors should have been centrifuged immediately after blood collection, not be older than 7 days, and stored at $2-8$ C. If these pre-mortem samples are not available, post-mortem blood may be used, which according to the current guidelines has to be taken only up to $24 \mathrm{~h}$ post mortem. After death, blood is modified, for example by hemolysis, autolysis, and bacterial growth. This may alter the structure of infectious markers and could lead to falsepositive or false-negative results.

The requirements of test systems for detection of HIV, $\mathrm{HCV}$ and $\mathrm{HBV}$ infections within the European Union are defined by the Directive 98/79/EC and the Common Technical Specifications (CTS). The CTS require the use of test assays with CE marking. Unfortunately, most CE-marked test equipment is not validated for testing post-mortem blood. To our knowledge, actually only chemiluminescent immunoassays (ABBOTT PRISM) are licensed for the testing of cadaveric serum/plasma samples from non-heart beating donors. The Paul-Ehrlich-Institut (PEI), the German regulatory authority responsible also for tissue preparations, recommends the validation of all test systems used for serological investigation of post-mortem blood samples. In this study we validated the serological testing for anti-HIV-1/2, anti-HCV, HBsAg, and anti-HBc from post-mortem blood on the Siemens-BEP-III Automatic System according to standardized procedures.

\section{Material and Methods}

\section{Principle of Validation}

Sets of pre- and post-mortem sera were obtained from cornea donors. Infectious disease serology results were compared for the respective donor. It was verified whether sera of donors who were test-negative before death with a validated test system were also negative when tested post mortem. As no relevant number of donors positive for the respective infectious disease markers was expected, the negative sera were spiked with a quantity of known positive sera which, in pre-mortem sera, give low-positive and high-positive results in order to exclude false-negativity through post-mortem modifications of donor blood.
Table 1. Protocol of anti-HCV spiking

\begin{tabular}{lll}
\hline & Standard high & Standard low \\
\hline Target concentration & $1: 500$ dilution of the PEI standard & $1: 5,000$ dilution of the PEI standard \\
Pre-dilution & $40 \mu \mathrm{l}$ from the original tube $+360 \mu \mathrm{l}$ serum* & $4 \mu \mathrm{l}$ from the original tube $+396 \mu \mathrm{l}$ serum* \\
Pipetting, $\mu \mathrm{l}$ & $1: 50$ of pre-dilution & $1: 50$ of pre-dilution \\
& $10 \mu \mathrm{l}$ pre-dilution $+490 \mu \mathrm{l}$ post-mortem serum & $10 \mu \mathrm{l}$ pre-dilution $+490 \mu \mathrm{l}$ post-mortem serum \\
\hline *Negative blood donor serum. & \\
\hline
\end{tabular}

\begin{tabular}{lll}
\hline & Standard high & Standard low \\
\hline Target concentration & 1 PEI U/ml & 0.05 PEI U/ml (1:20) \\
Pre-dilution & none & $100 \mu$ from the original tube $+1,900 \mu l$ serum* \\
Pipetting, $\mu \mathrm{l}$ & $\begin{array}{l}5 \mu \mathrm{l} \text { from the original tube }+495 \mu \mathrm{l} \text { post-mortem } \\
\text { serum }\end{array}$ & $\begin{array}{l}5 \mu \mathrm{l} \text { of } 1: 20 \text { pre-dilution }+495 \mu \mathrm{l} \text { post-mortem } \\
\text { serum }\end{array}$ \\
\hline *Negative blood donor serum. & \\
\hline
\end{tabular}

Table 2. Protocol of HBsAg spiking 
Bood Samples

During the time period from February to April 2010, pre- and post-mortem blood samples were collected from 20 cornea donors of the University Tissue Bank of the Charité, Cornea Bank Berlin, Campus VirchowClinic, Germany. For the HIV-low spiking test, additional samples of 20

Table 3. Protocol of anti-HBc spiking

\begin{tabular}{ll}
\hline & Standard low \\
\hline Target concentration & $2 \mathrm{IU} / \mathrm{ml}$ \\
Pre-dilution & none \\
Pipetting, $\mu \mathrm{l}$ & $\begin{array}{l}10 \mu \mathrm{l} \text { from the original tube }+490 \mu \mathrm{l} \text { post- } \\
\text { mortem serum }\end{array}$ \\
\hline
\end{tabular}

cornea donors were collected during the time period from May to August 2010. Age and sex of the donors as well as the time of post-mortem sampling were documented. Immediately after standardized blood sampling (skin disinfection, puncture of the subclavian vein with sterile equipment, obtaining at least $6 \mathrm{ml}$ post-mortem whole blood), the samples were centrifuged with 10,000 rpm for $5 \mathrm{~min}$ (Hettich Table Centrifuge Universal, Tuttlingen, Germany). The serum was divided in three portions and frozen at $-30 \pm 5{ }^{\circ} \mathrm{C}$. The volume of samples per portion was about $2 \mathrm{ml}$. 12-16 h before measurement, the samples were transferred to the refrigerator at $2-8{ }^{\circ} \mathrm{C}$.

\section{Spiking of Post-mortem Serum Samples}

The PEI provides reference material for anti-HIV-1/2, HBsAg, anti-HBc and anti-HCV spiking. The following WHO reference materials and PEI standards were used for the validation study:

- HCV: PEI anti-HCV IgG reference material, $500 \mu \mathrm{l}$ after reconstitution
Table 4. Protocol of anti-HIV spiking

Table 5. Results of anti-HCV test series

\begin{tabular}{lll}
\hline & Standard high & Standard low \\
\hline Target concentration & $1: 500$ dilution of the PEI standard & $1: 5,000$ dilution of the PEI standard \\
Pre-dilution & $50 \mu \mathrm{l}$ from the original tube $+450 \mu \mathrm{l} \mathrm{serum*}$ & $5 \mu \mathrm{l}$ from the original tube $+495 \mu \mathrm{l}$ serum* \\
Pipetting, $\mu \mathrm{l}$ & $1: 50$ of pre-dilution & $1: 50$ of pre-dilution \\
& $10 \mu \mathrm{l}$ pre-dilution $+490 \mu \mathrm{l}$ post-mortem serum & $10 \mu \mathrm{l}$ pre-dilution $+490 \mu \mathrm{l}$ post-mortem serum \\
\hline *Negative blood donor serum. & \\
\hline
\end{tabular}

\begin{tabular}{|c|c|c|c|c|c|c|}
\hline Number & Age, years & Sex & PM time, $\mathrm{h}$ & Standard low* & Standard high* & $\begin{array}{l}\text { Control* } \\
\text { (without spiking) }\end{array}$ \\
\hline 1 & 73 & $\mathrm{f}$ & 31 & 1.655 & 3.821 & 0.016 \\
\hline 2 & 69 & $\mathrm{~m}$ & 44 & 1.527 & 3.206 & 0.032 \\
\hline 3 & 70 & $\mathrm{f}$ & 8 & 1.629 & 3.523 & 0.013 \\
\hline 4 & 59 & $\mathrm{~m}$ & 37 & 1.033 & 3.315 & 0.012 \\
\hline 5 & 76 & $\mathrm{f}$ & 39 & 1.787 & 3.098 & 0.126 \\
\hline 6 & 67 & $\mathrm{~m}$ & 38 & 1.542 & 3.216 & 0.013 \\
\hline 7 & 70 & $\mathrm{~m}$ & 50 & 1.770 & 3.425 & 0.038 \\
\hline 8 & 77 & $\mathrm{f}$ & 27 & 1.631 & 3.295 & 0.017 \\
\hline 9 & 64 & $\mathrm{~m}$ & 24 & 1.742 & 3.293 & 0.014 \\
\hline 10 & 62 & $\mathrm{~m}$ & 52 & 1.677 & 3.213 & 0.019 \\
\hline 11 & 74 & $\mathrm{~m}$ & 48 & 1.733 & 3.374 & 0.029 \\
\hline 12 & 77 & $\mathrm{~m}$ & 25 & 1.587 & 3.028 & 0.013 \\
\hline 13 & 53 & $\mathrm{f}$ & 12 & 1.731 & 3.318 & 0.018 \\
\hline 14 & 58 & $\mathrm{~m}$ & 20 & 1.690 & 3.171 & 0.051 \\
\hline 15 & 66 & $\mathrm{f}$ & 31 & 1.835 & 3.492 & 0.018 \\
\hline 16 & 75 & $\mathrm{~m}$ & 44 & 1.721 & 3.414 & 0.016 \\
\hline 17 & 79 & $\mathrm{~m}$ & 45 & 1.846 & 3.696 & 0.015 \\
\hline 18 & 65 & $\mathrm{~m}$ & 42 & 1.623 & 3.368 & 0.038 \\
\hline 19 & 49 & $\mathrm{~m}$ & 52 & 1.601 & 3.243 & 0.035 \\
\hline 20 & 64 & $\mathrm{~m}$ & 29 & 1.432 & 3.245 & 0.023 \\
\hline NEG & & & & & & 0.015 \\
\hline $\mathrm{NEG}$ & & & & & & 0.014 \\
\hline NEG & & & & & & 0.016 \\
\hline NEG & & & & & & 0.016 \\
\hline POS & & & & & & 0.938 \\
\hline POS & & & & & & 1.029 \\
\hline
\end{tabular}


Table 6. Results of HBsAg test series

\begin{tabular}{|c|c|c|c|c|c|c|}
\hline Number & Age, years & Sex & PM time, $\mathrm{h}$ & $\begin{array}{l}\text { Standard } \\
\text { low* }\end{array}$ & $\begin{array}{l}\text { Standard } \\
\text { high* }\end{array}$ & $\begin{array}{l}\text { Control* } \\
\text { (without spiking) }\end{array}$ \\
\hline 1 & 70 & $\mathrm{f}$ & 8 & 0.235 & 2.748 & 0.026 \\
\hline 2 & 49 & $\mathrm{~m}$ & 52 & 0.218 & 1.830 & 0.059 \\
\hline 3 & 64 & $\mathrm{~m}$ & 29 & 0.330 & 2.648 & 0.043 \\
\hline 4 & 73 & f & 31 & 0.334 & 2.798 & 0.037 \\
\hline 5 & 76 & f & 39 & 0.357 & 2.319 & 0.023 \\
\hline 6 & 74 & $\mathrm{~m}$ & 48 & 0.145 & 1.145 & 0.033 \\
\hline 7 & 70 & $\mathrm{~m}$ & 50 & 0.178 & 1.744 & 0.022 \\
\hline 8 & 77 & $\mathrm{~m}$ & 25 & 0.313 & 3.147 & 0.037 \\
\hline 9 & 64 & $\mathrm{~m}$ & 24 & 0.379 & 3.046 & 0.033 \\
\hline 10 & 59 & $\mathrm{~m}$ & 37 & 1.110 & 3.271 & 0.045 \\
\hline 11 & 62 & $\mathrm{~m}$ & 52 & 0.374 & 3.048 & 0.034 \\
\hline 12 & 69 & $\mathrm{~m}$ & 44 & 0.252 & 2.297 & 0.027 \\
\hline 13 & 58 & $\mathrm{~m}$ & 20 & 0.263 & 2.373 & 0.034 \\
\hline 14 & 79 & $\mathrm{~m}$ & 45 & 0.222 & 1.992 & 0.020 \\
\hline 15 & 53 & f & 12 & 0.299 & 2.445 & 0.047 \\
\hline 16 & 65 & $\mathrm{~m}$ & 42 & 0.141 & 1.432 & 0.032 \\
\hline 17 & 67 & $\mathrm{~m}$ & 38 & 0.050 ** & $0.409 * *$ & 0.033 \\
\hline 18 & 75 & $\mathrm{~m}$ & 44 & 0.219 & 2.123 & 0.023 \\
\hline 19 & 77 & $\mathrm{f}$ & 27 & 0.209 & 1.778 & 0.029 \\
\hline 20 & 66 & $\mathrm{f}$ & 31 & 0.253 & 2.535 & 0.024 \\
\hline NEG & & & & & & 0.027 \\
\hline NEG & & & & & & 0.026 \\
\hline NEG & & & & & & 0.029 \\
\hline NEG & & & & & & 0.027 \\
\hline POS & & & & & & 1.129 \\
\hline POS & & & & & & 1.174 \\
\hline \multicolumn{7}{|c|}{$\begin{array}{l}\text { PM }=\text { Post-mortem time. } \\
\text { *OD (optical density); OD-reactive (cut off): }>0.077 \text {; kit-intern controls: NEG }-0.010 \text { to } \\
0.150 \text { POS } 0.700-9 ., 999 . \\
\text { **Incorrect pipetting. }\end{array}$} \\
\hline
\end{tabular}

- HBV: HBsAg: PEI HBsAg ad 1,000 standard, 100 PEI U/ml, $600 \mu \mathrm{l}$

- HBV: anti-HBc IgG (WHO) NIBSC code: 95/522, $100 \mathrm{IU} / \mathrm{ml}, 500 \mu \mathrm{l}$

- HIV: anti-HIV-1: PEI anti-HIV-IV reference material, $500 \mu \mathrm{l}$ after reconstitution.

The standards may be ordered at: www.pei.de/cln_170/nn_154416/SharedDocs/Downloads/EN/ivd/ivd-order-list.html.

The first aliquot of the post-mortem sample was tested unspiked as a negative control, the second aliquot was spiked with a high dilution of antigen or antibody, with expected results near the cut-off value (low-spiked), and the third aliquot, except for anti-HBc, was spiked with a high concentration of the antigen or antibody (high-spiked). The spiking was performed using a calibrated Biomaster ${ }^{\circledR}$ Eppendorf pipette. The exact details of supplies and dilution volumes are shown in tables 1-4. The freezedried standards (PEI anti-HCV IgG, anti-HIV-IV) were dissolved in a sodium chloride solution (isotonic sodium chloride solution $0.9 \%$, Braun, Melsungen, Germany). The required pre-dilutions of the standards (antiHIV-IV, HBsAg ad 1,000 standard) were obtained by using serologically negatively tested human serum of blood donors. The blood sample volume per test was $500 \mu \mathrm{l}$.

\section{Test Kits}

The following test kits were used to test the samples:

- SIEMENS Enzygnost ${ }^{\circledR}$ HBsAg 6.0 [5]

- SIEMENS Enzygnost ${ }^{\circledR}$ Anti-HBc monoclonal (MONO HBc) [6]
- SIEMENS Enzygnost ${ }^{\circledR}$ Anti-HIV $1 / 2$ Plus [7]

- ORTHO ${ }^{\circledast}$ HCV 3.0 ELISA Test System with Enhanced SAVe [8].

All measurements were performed in the serological laboratory of the Charité - University Medicine Berlin, Institute of Transfusion Medicine, Campus Charité Mitte, on the BEP III System (Siemens Healthcare Diagnostics, Eschborn, Germany).

\section{Results}

\section{Tissue Donors}

Consent for tissue removal and serological tests were obtained in advance under the provisions of the German Transplantation Law (Transplantationsgesetz; TPG). All pre-mortal samples obtained up to 7 days before death were unequivocally negative in all tests. The post-mortal blood samples were taken from 6 female and 14 male donors at the time of cornea removal. The median age of the donors was 68 years (49-77 years). The post-mortem blood samples were collected between 4 and $52 \mathrm{~h}$ post mortem. The blood samples for the additional anti-HIV-low tests were taken from 10 female and 10 male donors at the time of cornea re- 
Table 7. Results of anti-HBc test series

\begin{tabular}{|c|c|c|c|c|c|}
\hline Number & Age, years & Sex & PM time, $\mathrm{h}$ & Standard low* & $\begin{array}{l}\text { Control* } \\
\text { (without spiking) }\end{array}$ \\
\hline 1 & 73 & $\mathrm{f}$ & 31 & 0.082 & 1.249 \\
\hline 2 & 69 & $\mathrm{~m}$ & 44 & 0.109 & 1.154 \\
\hline 3 & 70 & $\mathrm{f}$ & 8 & 0.080 & 1.376 \\
\hline 4 & 59 & $\mathrm{~m}$ & 37 & 0.089 & 1.693 \\
\hline 5 & 76 & $\mathrm{f}$ & 39 & 0.087 & 1.417 \\
\hline 6 & 67 & $\mathrm{~m}$ & 38 & 0.091 & 1.605 \\
\hline 7 & 70 & $\mathrm{~m}$ & 50 & 0.097 & 1.064 \\
\hline 8 & 77 & f & 27 & 0.093 & 1.011 \\
\hline 9 & 64 & $\mathrm{~m}$ & 24 & 0.080 & 1.526 \\
\hline 10 & 62 & $\mathrm{~m}$ & 52 & 0.086 & 1.279 \\
\hline 11 & 74 & $\mathrm{~m}$ & 48 & 0.101 & 1.328 \\
\hline 12 & 77 & $\mathrm{~m}$ & 25 & 0.076 & 1.513 \\
\hline 13 & 53 & $\mathrm{f}$ & 12 & 0.102 & 1.383 \\
\hline 14 & 58 & $\mathrm{~m}$ & 20 & 0.117 & 0.892 \\
\hline 15 & 66 & f & 31 & 0.078 & 1.028 \\
\hline 16 & 75 & $\mathrm{~m}$ & 44 & 0.074 & 1.528 \\
\hline 17 & 79 & $\mathrm{~m}$ & 45 & 0.106 & 1.285 \\
\hline 18 & 65 & $\mathrm{~m}$ & 42 & 0.085 & 1.377 \\
\hline 19 & 49 & $\mathrm{~m}$ & 52 & 0.067 & 1.271 \\
\hline 20 & 64 & $\mathrm{~m}$ & 29 & 0.105 & 1.521 \\
\hline NEG & & & & & 1.299 \\
\hline NEG & & & & & 1.324 \\
\hline NEG & & & & & 1.355 \\
\hline NEG & & & & & 1.333 \\
\hline POS & & & & & 0.016 \\
\hline POS & & & & & 0.017 \\
\hline \multicolumn{6}{|c|}{$\begin{array}{l}\text { PM }=\text { Post-mortem time. } \\
\text { *OD (optical density); OD-reactive (cut off): }<0.266 \text {, kit-intern controls: } \\
\text { NEG } 0.700-9.999, \text { POS }-0.010 \text { to } 0.100 \text {. }\end{array}$} \\
\hline
\end{tabular}

moval. The median age of the donors was 61.5 years (39-74 years). The blood samples were collected between 4 and $47 \mathrm{~h}$ post mortem.

\section{Anti-HCV Post-mortem Testing}

All unspiked samples were confirmed negative. Both the lowand high-spiked samples showed correct positive results for anti-HCV. False-negative or false-positive results were not observed. Furthermore, no differences depending on postmortem blood collection time, age, or sex could be demonstrated. The extinction of the samples did not change noticeably with increasing post-mortem removal time (table 5).

\section{HBsAg Post-mortem Testing}

20/20 unspiked samples were true-negative. All high-spiked samples, and 19/20 with the low-spiked samples tested for HBsAg showed correct positive results. In 1/20 samples (no. 17), the value for the low-spiked sample was in the range of the negative control and for the high-spiked sample remarkably lower than for the other 19 high-spiked samples. After examining sample no. 17, a pipetting error in the quantity of post-mortem serum could be determined as the cause (exces- sive total volume due to double-pipetting). No differences dependent on post-mortem blood collection time, age, or sex could be demonstrated. This means that the extinction of the samples did not change noticeably with increasing post-mortem removal time (table 6).

\section{Anti-HBc Post-mortem Testing}

All unspiked samples were true-negative. All low-spiked samples for anti-HBc showed true-positive results. Neither falsenegative, nor false-positive findings were recorded. No differences dependent on post-mortem blood collection time, age, or sex could be demonstrated, i.e., the extinction of the samples did not change noticeably with increasing post-mortem removal time (table 7). After consultation with the PEI, the validation of high-spiked samples was not performed.

\section{Anti-HIV Post-mortem Testing}

All unspiked samples were true-negative. No differences dependent on post-mortem blood collection time, age, or sex could be demonstrated, that is the extinction of the samples did not change noticeably with increasing post-mortem removal time (table 8). 
Table 8. Results of the first anti-HIV test series (see text)

\begin{tabular}{|c|c|c|c|c|c|c|}
\hline Number & Age, years & Sex & PM time, $\mathrm{h}$ & $\begin{array}{l}\text { Standard } \\
\text { low* }\end{array}$ & $\begin{array}{l}\text { Standard } \\
\text { high* }\end{array}$ & $\begin{array}{l}\text { Control } \\
\text { (without spiking) }\end{array}$ \\
\hline 1 & 73 & $\mathrm{f}$ & 31 & 0.333 & 2.198 & 0.057 \\
\hline 2 & 69 & $\mathrm{~m}$ & 44 & 0.159 & 1.243 & 0.057 \\
\hline 3 & 70 & $\mathrm{f}$ & 8 & 0.344 & 2.820 & 0.051 \\
\hline 4 & 59 & $\mathrm{~m}$ & 37 & $1.030^{* *}$ & 3.186 & 0.307 \\
\hline 5 & 76 & $\mathrm{f}$ & 39 & 0.207 & 1.196 & 0.041 \\
\hline 6 & 67 & $\mathrm{~m}$ & 38 & 0.337 & 2.783 & 0.064 \\
\hline 7 & 70 & $\mathrm{~m}$ & 50 & 0.368 & 2.742 & 0.051 \\
\hline 8 & 77 & $\mathrm{f}$ & 27 & 0.308 & 2.030 & 0.048 \\
\hline 9 & 64 & $\mathrm{~m}$ & 24 & 0.372 & 2.591 & 0.037 \\
\hline 10 & 62 & $\mathrm{~m}$ & 52 & $0.707 * *$ & 3.457 & 0.233 \\
\hline 11 & 74 & $\mathrm{~m}$ & 48 & 0.142 & 0.766 & 0.042 \\
\hline 12 & 77 & $\mathrm{~m}$ & 25 & 0.358 & 2.729 & 0.043 \\
\hline 13 & 53 & $\mathrm{f}$ & 12 & 0.326 & 1.700 & 0.037 \\
\hline 14 & 58 & $\mathrm{~m}$ & 20 & 0.259 & 1.752 & 0.040 \\
\hline 15 & 66 & $\mathrm{f}$ & 31 & 0.395 & 3.382 & 0.400 \\
\hline 16 & 75 & $\mathrm{~m}$ & 44 & 0.416 & 2.831 & 0.099 \\
\hline 17 & 79 & $\mathrm{~m}$ & 45 & 0.369 & 2.900 & 0.044 \\
\hline 18 & 65 & $\mathrm{~m}$ & 42 & 0.358 & 2.327 & 0.067 \\
\hline 19 & 49 & $\mathrm{~m}$ & 52 & 0.268 & 1.595 & 0.056 \\
\hline 20 & 64 & $\mathrm{~m}$ & 29 & 0.174 & 1.562 & 0.043 \\
\hline NEG & & & & & & 0.082 \\
\hline NEG & & & & & & 0.065 \\
\hline NEG & & & & & & 0.060 \\
\hline NEG & & & & & & 0.063 \\
\hline POS & & & & & & 1.735 \\
\hline POS & & & & & & 1.676 \\
\hline \multicolumn{7}{|c|}{$\begin{array}{l}\text { PM }=\text { Post-mortem time. } \\
* \text { OD (optical density); OD-reactive (cut off): >0.468, kit-intern controls: NEG }-0.010 \text { to } 0.150 \text {, POS 0.700-9.999. } \\
* * \text { True positive. }\end{array}$} \\
\hline
\end{tabular}

All high-spiked samples for anti-HIV showed true-positive results. However, in the first measurement series of low-spiked samples we found 18/20 samples false-negative and only 2/20 samples true-positive (table 8). Thus, we assumed that the chosen dilution of 1:5,000 was too low to generate reactive results. Therefore, we repeated the measurement with a dilution of 1:4,000 using 10 new low-spiked samples. All results were truepositive, but the results of the 1:4,000 dilution showed unexpected high values (table 9). Because of this, we performed a second test series with 20 low-spiked samples using the dilution 1:5,000 (table 10). In order to additionally investigate both the influence of the time period before centrifugation and the storage conditions, the cadaveric blood samples no. 11-20 were immediately centrifuged after blood collection and frozen, while the samples no. 1-10 were handled as whole blood for up to 7 days, stored at $2-8{ }^{\circ} \mathrm{C}$ in the refrigerator, and centrifuged only directly prior to measurement.

Including the results of the comparison 1:4,000 versus 1:5,000 dilution (table 9), 28/30 of the low-spiked samples for anti-HIV showed true-positive results. One result (sample 4, table 10) with a reactive negative control due to pipette clotting was discarded. False-negative results were obtained in
1/30 samples (sample 1, table 10). 18/20 of the unspiked samples were true-negative (table 10). In 2/20 samples a pipette blockage during the analysis occurred so that the findings could not be counted. Here again, no differences dependent on post-mortem blood collection time, age, or sex could be demonstrated, that is, the extinction of the samples did not change noticeably with increasing post-mortem removal time.

\section{Discussion}

Post-mortem modifications might give false-negative or falsepositive results in infectious disease testing due to hemolysis, autolysis, and bacterial growth. Most CE-marked test equipment for infectious serology testing is not validated for testing post-mortem blood. A recently published study shows that no false-negative results appear when taking blood up to $48 \mathrm{~h}$ post mortem under standardized conditions from HIV-, HCV-, and/or HBV-infected cadavers [9]. Up to now no study compares the results of infection testing in pre-mortem and postmortem samples of the same donors. Hence, this study was performed using low-spiked and high-spiked post-mortem 
Table 9. Comparison of the low-standard dilutions for the anti-HIV test series*

\begin{tabular}{|c|c|c|c|}
\hline Number** & $\begin{array}{l}\text { Low standard } \\
1: 4,000\end{array}$ & $\begin{array}{l}\text { Low standard } \\
1: 5,000\end{array}$ & Controls \\
\hline 1 & 2.068 & 1.006 & \\
\hline 2 & 1.972 & 0.930 & \\
\hline 3 & 1.816 & 0.866 & \\
\hline 4 & 1.984 & 0.902 & \\
\hline 5 & 1.969 & 0.876 & \\
\hline 6 & 2.028 & 0.923 & \\
\hline 7 & 1.743 & 0.750 & \\
\hline 8 & 1.980 & 0.930 & \\
\hline 9 & 2.182 & 0.873 & \\
\hline 10 & 2.041 & 0.847 & \\
\hline NEG & & & 0.098 \\
\hline NEG & & & 0.076 \\
\hline NEG & & & 0.076 \\
\hline NEG & & & 0.077 \\
\hline POS & & & 1.652 \\
\hline POS & & & 1.594 \\
\hline
\end{tabular}

serum of 20 deceased cornea donors with pre-mortem negative test results according to the recommendation of the PEI.

The results of this study show that the serological testing of post-mortem blood samples for anti-HIV (SIEMENS Enzygnost $^{\circledR}$ Anti-HIV 1/2 Plus), HBsAg (SIEMENS Enzygnost ${ }^{\circledR}$ HBsAg 6.0), anti-HCV (ORTHO ${ }^{\circledR}$ HCV 3.0 ELISA Test System with Enhanced SAVe), and anti-HBc (SIEMENS Enzygnost $^{\circledR}$ Anti-HBc monoclonal (HBc MONO)) on the BEP-III automatic system from Siemens is suitable for routine testing and leads to valid results. No false-negative or false-positive results were shown in the test series for $\mathrm{HBsAg}$, anti-HCV, and anti-HBc. In the first test series of the HIV-low validation, false-negative findings occurred in almost all the tests. The cause of the false-negative reactions should be considered as a systematic pipetting error. In a second test series of the anti-HIV validation, the low-spiked samples were tested true-positive, and the values were suitable as a standard low control. The false-negative result in one case is probably caused by the pre-analytical conditions. Because this sample was stored uncentrifuged in the refrigerator and the serum was obtained just before spiking, inhibiting effects on the added spiking material may have occurred. This could also ex-
Table 10. Results of the second anti-HIV test series (retesting low-standard) ${ }^{\mathrm{a}}$

\begin{tabular}{|c|c|c|c|c|c|}
\hline Number & Age, years & Sex & PM time, $\mathrm{h}$ & $\begin{array}{l}\text { Low standard } \\
1: 5,000\end{array}$ & $\begin{array}{l}\text { Control } \\
\text { (without spiking) }\end{array}$ \\
\hline 1 & 56 & $\mathrm{~m}$ & 34 & 0.345 & 0.030 \\
\hline 2 & 69 & $\mathrm{~m}$ & 17 & 0.753 & 0.051 \\
\hline 3 & 49 & $\mathrm{~m}$ & 49 & 0.665 & 0.432 \\
\hline 4 & 69 & $\mathrm{f}$ & 16 & $\geq 4.00 * *$ & $\geq 4.00 * *$ \\
\hline 5 & 56 & f & 25 & 0.579 & 0.054 \\
\hline 6 & 70 & $f$ & 40 & 0.976 & 0.034 \\
\hline 7 & 74 & f & 20 & 1.350 & 0.036 \\
\hline 8 & 73 & $\mathrm{~m}$ & 32 & 0.666 & 0.039 \\
\hline 9 & 74 & $\mathrm{~m}$ & 4 & 0.831 & 0.089 \\
\hline 10 & 60 & $\mathrm{~m}$ & 47 & 0.816 & 0.019 \\
\hline 11 & 74 & $\mathrm{f}$ & 34 & 2.064 & 0.101 \\
\hline 12 & 45 & $\mathrm{~m}$ & 49 & 1.546 & 0.021 \\
\hline 13 & 71 & $f$ & 31 & 1.874 & 0.029 \\
\hline 14 & 39 & $\mathrm{~m}$ & 46 & 1.455 & 0.036 \\
\hline 15 & 49 & f & 24 & 1.495 & 0.040 \\
\hline 16 & 61 & $f$ & 18 & 1.106 & 0.047 \\
\hline 17 & 62 & $f$ & 27 & 1.177 & 0.041 \\
\hline 18 & 64 & $\mathrm{~m}$ & 30 & 1.731 & 0.031 \\
\hline 19 & 57 & $\mathrm{~m}$ & 38 & 1.384 & $\geq 4.00 * *$ \\
\hline 20 & 50 & $f$ & 32 & 2.777 & 0.037 \\
\hline NEG & & & & & 0.053 \\
\hline NEG & & & & & 0.043 \\
\hline NEG & & & & & 0.068 \\
\hline NEG & & & & & 0.056 \\
\hline POS & & & & & 1.601 \\
\hline POS & & & & & 1.650 \\
\hline \multicolumn{6}{|c|}{$\begin{array}{l}\text { PM }=\text { Post-mortem time. } \\
{ }^{2} \mathrm{OD} \text { (optical density); OD-reactive (cut off): }>0.455 \text {; kit-intern controls: NEG }-0.010 \text { to } 0.150 \text {, } \\
\text { POS } 0.700-9.999 ; \text { sample } 1-10 \text { : storage at } 2-8{ }^{\circ} \mathrm{C} \text {; samples } 11-20 \text { : serum storage at }-30 \mathrm{C} \text {. } \\
* * \text { Pipette blockage. }\end{array}$} \\
\hline
\end{tabular}


plain the significantly lower optical density (OD) values of the samples $1-10\left(2-8{ }^{\circ} \mathrm{C}\right.$ storage $)$ compared with the samples 11-20 (frozen immediately after centrifugation at $-30^{\circ} \mathrm{C}$ ) with the same time interval between spiking and measuring. In this respect, immediate centrifugation after removal may be a mandatory pre-analytical requirement. Further investigations are needed to prove this hypothesis. In addition, it must be taken into account that post-mortem serum could rarely lead to blockage of pipetting systems due to clotting phenomena.

The concentrations of the spiking materials proposed by the PEI were suitable to fulfill the requirements of our validation. From the perspective of the authors, this validation should be extended to include spiked samples from living donors in order to detect any differences between pre- and postmortem blood.
In our opinion the methodology described in the present study may be used as guidance for validation of serological infection diagnosis of post-mortem blood samples.

\section{Acknowledgment}

The authors wish to thank Dr. Sigrid Nick (Paul-Ehrlich-Institut, Federal Institute for Vaccines and Biomedical Medicine) for her assistance in designing the study and her expert opinion and Karin Jakstadt and Lutz Schmidt for technical assistance in the implementation of the experiments.

\section{Disclosure Statement}

The authors declared no conflict of interest.

\section{References}

1 Bundesärztekammer: Richtlinien zur Gewinnung von Blut und Blutbestandteilen und zur Anwendung von Blutprodukten (Hämotherapie) [Guidelines for the preparation of blood and blood components and for the application of blood products (hemotherapy)]. Bundesanzeiger vom 09.07.2010;101a:1-40.

2 European Union: Directive 2004/23/EC of the European Parliament and of the Council of 31 March 2004 on Setting Standards of Quality and Safety for the Donation, Procurement, Testing, Processing, Preservation, Storage and Distribution of Human Tissues and Cells. Official Journal of the European Union, 04.07;2004, 102:48-58.

3 European Union: Commission Directive 2006/17/ EC of 8 February 2006 Implementing Directive 2004/23/EC of the European Parliament and of the Council as Regards Certain Technical Requirements for the Donation, Procurement and Testing of Human Tissues and Cells. Official Journal of the European Union, 02.09.2006;38:40-52.
4 Federal Ministry of Justice: TPG-Gewebeverordnung (TPG-GewV) [Regulation on quality and safety requirements regarding tissue removal and transplantation according to the German transplant law]. 26 March 2008, BGBl I:512.

5 Siemens Enzygnost ${ }^{\circledR}$ HBsAg6.0: Enzyme Immunoassay for the Qualitative Detection of Hepatitis B (surface) Antigen in Human Serum or Plasma; Edition: December 2008.

6 Siemens Enzygnost ${ }^{\circledR}$ Anti-HBc Monoclonal (MONO $\mathrm{HBc}$ ): Enzyme Immunoassay for Qualitative Detection of Antibodies Against Hepatitis B (core) Antigen in Serum or Plasma; Edition: November 2007.
7 Siemens Enzygnost ${ }^{\circledR}$ Anti-HIV 1/2 Plus: Enzyme Immunoassay for the Detection of Antibodies Against HIV1, HIV2 and HIV1 (subtype O) Antigens; Edition: March 2007.

8 ORTHO ${ }^{\circledast}$ HCV 3.0 ELISA Test System with Enhanced SAVe (Sample Addition Verification): A Qualitative Enzyme Immunoassay for the Detection of Antibodies to Hepatitis C Virus (anti-HCV) in Human Serum or Plasma; Edition: January 2008.

9 Edler C, Wulff B, Schroeder AS, Wilkemeyer I, Polywka S, Meyer T, Kalus U, Pruss A: A prospective time course study on serological testing for human immunodefi-ciency virus, hepatitis $\mathrm{B}$ virus and hepatitis $\mathrm{C}$ virus with blood samples taken up to 48 hours after death. J Med Microbiol 2011;60:920-926. 